\title{
A MODEL OF COLLABORATIVE PROCESS PLANNING SYSTEM (e-CAPP)
}

\author{
Mijodrag Milošević, Dejan Lukić, Stevo Borojević, Goran Šimunović, Aco Antić
}

Original scientific paper

The current tendency of global competitiveness requires the development of distributed application systems that are used in the product design, the production preparation, as well as directly in the manufacturing processes. In this way, distributed design and production environments created actually exceed traditional physical and time constraints. The application of internet/intranet technologies enables the connection and integration of geographically dislocated designers, experts, systems, resources and services. After analysing new tendencies in planning and preparing the distributed manufacturing, a need to develop a collaborative system in the area of process planning is identified. Activities related to process planning in distributed environments are often realized by applying the extended CAPP system whose knowledge base is increased and improved by the knowledge of geographically dislocated experts. The e-CAPP represents exactly such a collaborative system which can be effectively applied in the area of process planning.

Keywords: CAPP system; collaborative system; distributed manufacturing; e-manufacturing; process planning

Model kolaborativnog sustava za projektiranje tehnoloških procesa izrade proizvoda (e-CAPP)

Izvorni znanstveni rad Današnja tendencija globalne konkurentnosti zahtijeva razvoj distribuiranih aplikacionih sustava koji se koriste u projektiranju proizvoda, pripremi proizvodnje, kao i izravno u procesu proizvodnje. Na ovaj način se stvaraju distribuirana projektantska i proizvodna okruženja koja nadilaze tradicionalna fizička i vremenska ograničenja. Primjenom Internet/intranet tehnologije povezuju se i integriraju geografski dislocirani projektanti, eksperti, sustavi, resursi i servisi. Analizom novih tendencija u planiranju i pripremi distribuirane proizvodnje uočena je potreba za razvojem kolaborativnog sustava u oblasti projektiranja tehnoloških procesa. Aktivnosti vezane za projektiranje tehnoloških procesa izrade se u distribuiranim okruženjima često realiziraju primjenom proširenog CAPP sustava čija je baza znanja proširena i unaprijeđena znanjem dislociranih eksperata. e-CAPP upravo predstavlja jedan takav kolaborativni sustav namijenjen projektiranju tehnoloških procesa izrade proizvoda.

Ključne riječi: CAPP sistem; distribuirana proizvodnja; e-proizvodnja; kolaborativni sistem; tehnološki proces

\section{Introduction}

The development of a modern product design and process planning systems requires the application of new concepts and models that include the dynamic coordination of all activities and stages with the purpose of improving the quality of the product design and process planning $[1,2]$. Numerous software systems and techniques aimed at improving design, planning and manufacturing processes can be implemented by the development of information and Internet technologies [3]. Designers have a constant need to cooperate and participate in the exchange of information, activities and knowledge in order to realize common goals and interests. The degree of complexity of mutual cooperation dictates the use of different cooperative strategies (Fig. 1).

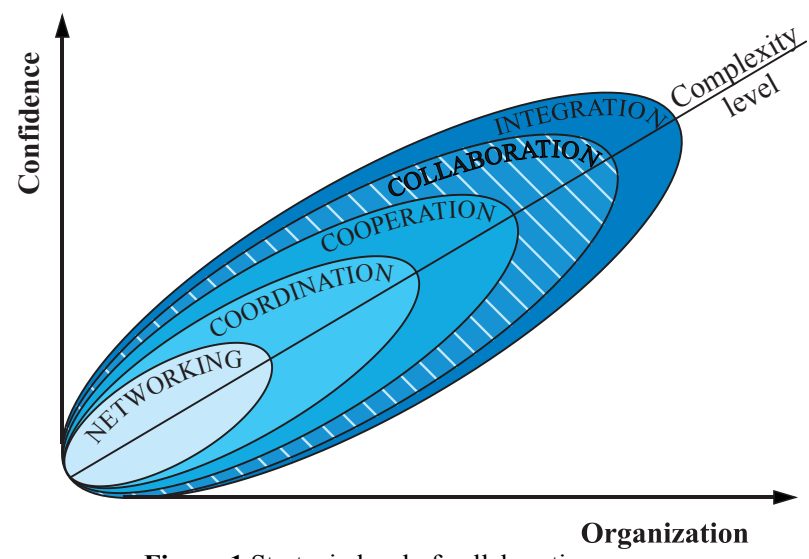

Figure 1 Strategic level of collaborative processes

The basic level of cooperation is networking, which is also a necessary condition for the establishment of a collaborative process. Higher levels are coordination and cooperation, which require a better organizational structure for the information exchange and distribution of activities and resources. Collaboration, as the next level of the collaborative process, allows individuals and organizations to actively exchange knowledge and thus effectively achieve common goals [4]. Finally, integration represents the highest level of cooperation where the complete connection of organizational and administrative structures is achieved.

Web based collaborative process planning environments developed in the recent years enable the distribution and collaboration at a global level $[5,6]$. Using the Internet, these integrated collaborative environments for product development can provide significant benefits $[7,8]$ :

- Integration of enterprises at a global level in terms of knowledge and information exchange,

- Possibility to connect heterogeneous software systems based on different platforms,

- Open structure of computer systems and services which considers the integration of a new subsystem or removal of an existing subsystem without compromising the integrity, and

- Cooperation and interaction on man-man or mansystem relations on different collaborative levels with a fast and efficient access to information.

Analysing new tendencies in the planning and preparation of the distributed manufacturing, a need to develop a collaborative system in the area of process planning has been identified. Activities related to process planning in distributed environments are often realized using CAPP systems [9]. Thereby, procedures that take 
engineering drawings, bills of materials and other technological specifications as input information are applied and accomplished. Their purpose is the identification and selection of process plans, resources, operations and other parameters necessary to transform a raw material into a finished product. CAPP tools integrate decision-making mechanisms and knowledge bases in a way that they build the basis for the definition of process plans [10]. However, their integration with other functions in the enterprise, such as financial flows, production planning, material resource planning, production control, quality control, procurement, etc., is not so simple [11]. Still, this integration is essential for enterprises that participate in the collaborative process with other enterprises in order to accelerate the development of new products where competitiveness in the global market represents the main motive [12].

A system for the collaborative process planning should ensure an effective cooperation between all relevant entities involved in the direct production preparation [13]. The main task of this system is an efficient global involvement of appropriate human resources in the decision-making process when defining process plans for certain groups of products. However, assuming that a decision cannot be realized without adequate geometric and technological data, as well as the data about direct manufacturing conditions and resources, a collaborative system should provide an access to crucial data based on which the appropriate manufacturing solutions can be found. Also, a system should allow the archiving of obtained solutions for their future analysis and exploitation, as well as the generation of necessary documentation. Considering that a system such as this is applied in the area of distributed manufacturing, the imperative is to use information and communication technologies, as well as the Internet technologies above all [14].

\section{Defining the structure of collaborative environment}

The development of a system for collaborative process planning includes a preliminary analysis of collaborative environment and its basic modules in which the predicted collaborative activities are realized. One of the entities that initiate a collaborative process is the external enterprise which orders a product, assembly or some individual part from the parent enterprise which deals with manufacturing and process planning as well. The parent enterprise can operate in distributed manufacturing conditions, which involves physically dispersed elements of the production plant or planning departments. It is implied that such an extended enterprise structure [15] operates on the principles of emanufacturing [16]. Likewise, it requires the implementation of an appropriate collaborative system that allows a direct cooperation and a prompt transfer of necessary information between all segments of the enterprise.

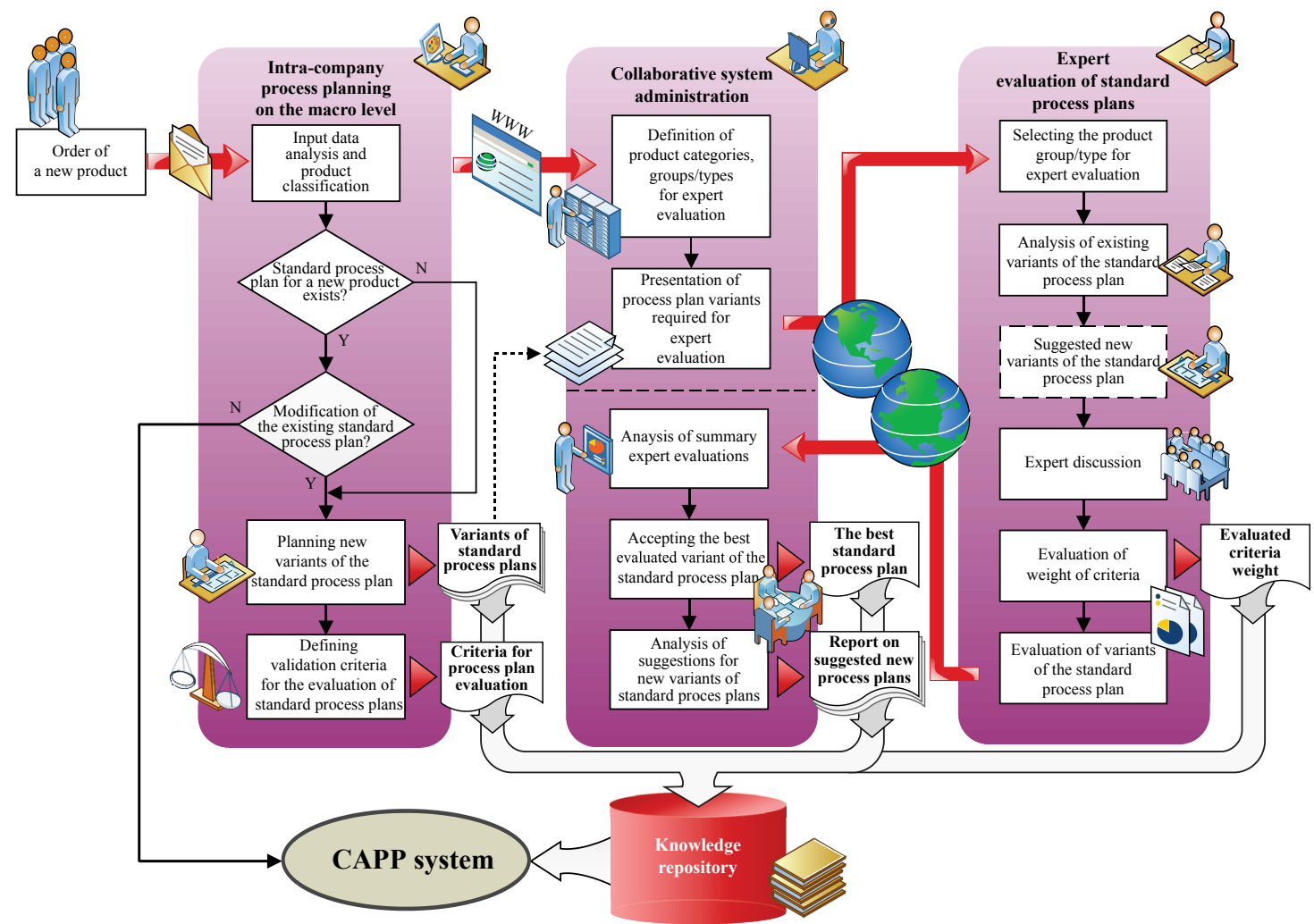

Figure 2 Structure of the collaborative environment for process planning

Predicted collaborative environment, in addition to the CAPP system, includes three basic modules (Fig. 2):

- Module for intra-company process planning,

- Module for collaborative system administration, and

- Module for the expert evaluation of process plans.

\subsection{Module for intra-company process planning}

Product orders primarily initiate the analysis of input data performed by engineers within the parent enterprise. The order should include the basic input geometric and technological data needed for the process planning and 
direct manufacturing of the ordered product. A valid order includes a detailed product drawing, production volume, required deadlines, as well as additional specific requirements that have a direct or indirect influence on the process plan, or the production process in general.

A new routing sheet for the process plan is needed in two cases:

1) For a completely new product that does not belong to any of the existing product groups, and

2) If it is determined that the existing standard process plan for the specific product group to which the ordered product belongs is inadequate and requires appropriate modifications.

Main approach in these cases is the planning of a larger number of new variants of process plans for a new product or the existing product group which the ordered product belongs to. This applies if it is determined that the standard process plan for this product group can be improved. Based on the characteristics of standard products, as well as the production volume, engineers and experts define the type of raw materials, and then the variants of process plans, according to Fig. 3.

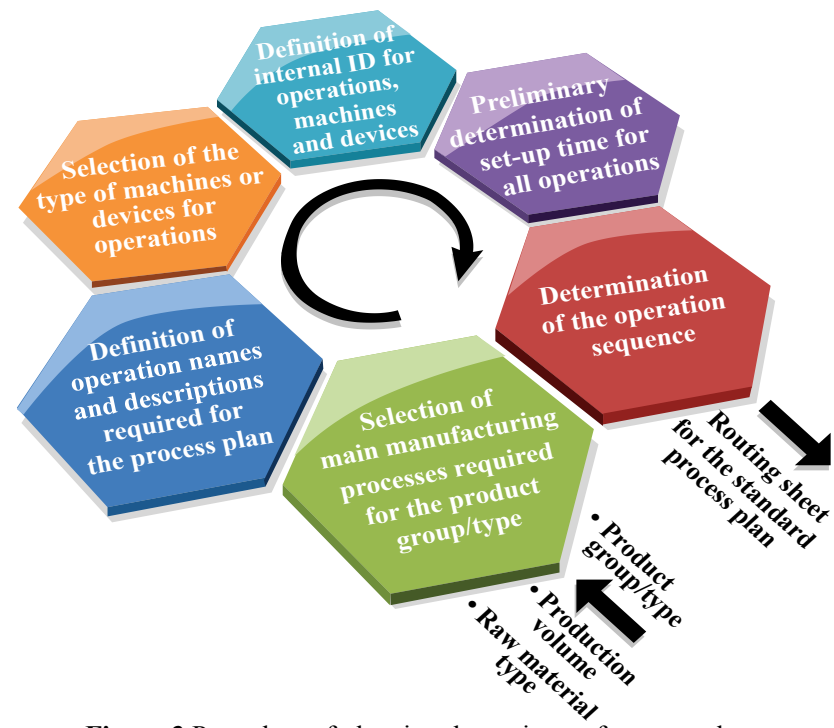

Figure 3 Procedure of planning the variants of process plans

Furthermore, engineers and experts within the parent enterprise also define criteria for the evaluation of process plans. It is anticipated that, by applying these criteria, geographically dislocated experts perform the evaluation of suggested solutions using a collaborative system. Thus, they contribute to finding the best process plans. Also, experts will be able to complement the existing suggestions with the completely new and their own solutions. The best evaluated and verified solutions will become standard process plans in the CAPP system. In the future, they will be applied to all products belonging to the appropriate product groups or product types.

\subsection{Module for collaborative system administration}

Administration of a collaborative system involves the coordination and synchronization of collaborative activities in order to efficiently operate the entire collaborative process. It is very important to ensure a safe and secure function of the system, data privacy and consistency, and the control of discussions and user profiles.

One of the initial activities in the administration module of collaborative environment is the definition of categories, types and groups of products whose process plans are evaluated by experts. Such distribution is directly related to the distribution within the specialized CAPP system, or the structure of a product family.

The final stage in the administration of the system refers to the analysis of expert evaluations, discussions, proposals and suggestions that will be followed after the completion of expert analysis. In the module for collaborative system administration, the overview of individual and summary evaluations is determined at the end of the expert evaluation. Likewise, the report on the proposed new variants of standard process plans for specific product groups is determined.

\subsection{Module for the expert evaluation of process plans}

Expert multi-criteria evaluation of alternative process plans represents one of the basic functions of the collaborative system. By means of an administration module, geometric and technological data related to the selected product type are presented to the experts. Based on these data, drawings and documents, the expert is able to perform all the necessary analysis before providing their own evaluation and declaring the offered manufacturing solutions.

Expert discussion is intended to be a method for mutual analysis, polemics, expression of own opinions, constructive suggestions and knowledge exchange. Expert discussion groups can be formed at the level of product categories, groups or types. In addition to the enabled knowledge exchange among dislocated experts, discussions are of great importance for engineers and experts from the parent enterprise.

Apart from being able to evaluate the alternatives of process plans on the basis of the proposed criteria established by the parent enterprise, experts can also define the importance of evaluation criteria. This can additionally improve the quality and accuracy of the summary expert evaluation.

\subsection{Knowledge repository}

Along with the knowledge exchange, the collection of engineering and expert knowledge and its storing for the future exploitation and analysis is the basic meaning of the implementation of the collaborative system. Knowledge repository includes data and information related to procedural knowledge, business rules, expert analysis, decision support, etc. This repository enables enterprises to use the contained information in the best way.

One part of this repository is the expert knowledge in the field of process planning. The expert knowledge that is formed within the predicted collaborative environment will be stored in this repository and subsequently used for the implementation in the direct production preparation.

Obtained standard operations and alternatives of process plans will be placed in the knowledge repository. 
An example of the routing sheet for the standard process plan for one part type is shown in Fig. 4. This repository also involves the reports generated in the administration module that are referred to expert suggestions for new manufacturing solutions. By analysing these reports, future process plans can be improved and the procurement of new equipment can be planned.

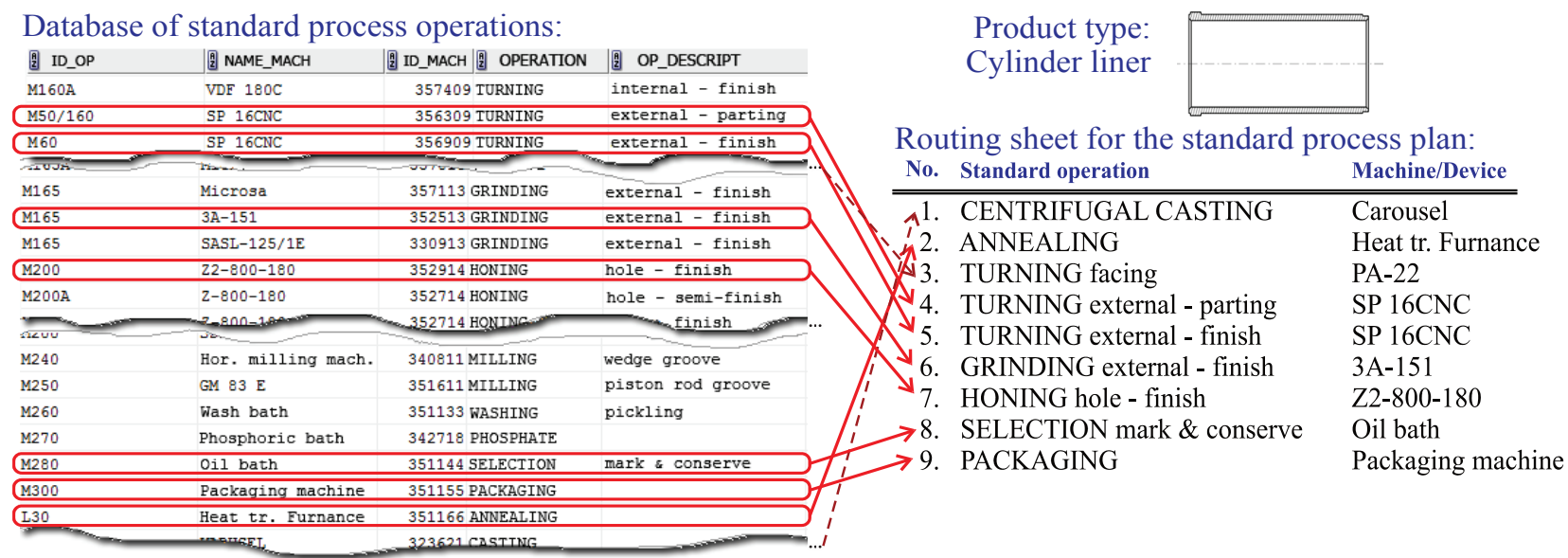

Figure 4 An example of a routing sheet for a standard process plan in the knowledge repository

\section{Specialized CAPP system}

Apart from human resources involved in the planning and evaluation of process plans, the collaborative environment requires the implementation of a specialized CAPP system. CAPP system is primarily aimed to the automated generation of process plans for specific product families from the product range of the parent enterprise. Macro process planning using the CAPP system is based on the variant method. This means that similar products or parts are manufactured in a similar way, which also means they have similar process plans as well.

Final process planning on the micro level, or the detailed specification of manufacturing operations, is based on the generative method.

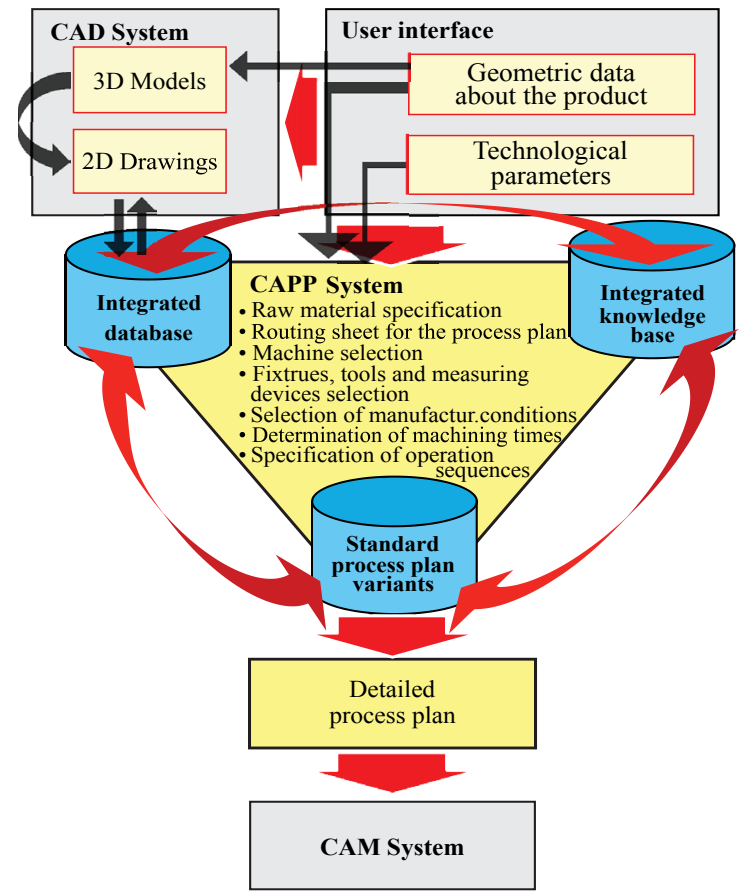

Figure 5 Components of the integrated $\mathrm{CAD} / \mathrm{CAPP} / \mathrm{CAM}$ system
CAPP system exists along with other CAx systems used in all stages of the product lifecycle. CAD and CAM systems are directly linked to the CAPP system which enables the automated generation of technical documentation and the preparation of manufacturing operations which are performed on $\mathrm{CNC}$ machines (Fig. 5).

The predicted collaborative system enables the improvement of the knowledge base for the selection of a raw material and the definition of the contents of process plans. These benefits are based on the evaluations and suggestions provided by geographically dislocated experts and specialists.

\subsection{Implementation stages of the specialized CAPP system}

Based on the order received from the external enterprise, an engineer from the parent enterprise has a role to perform an interactive classification of products in the system (Fig. 6).

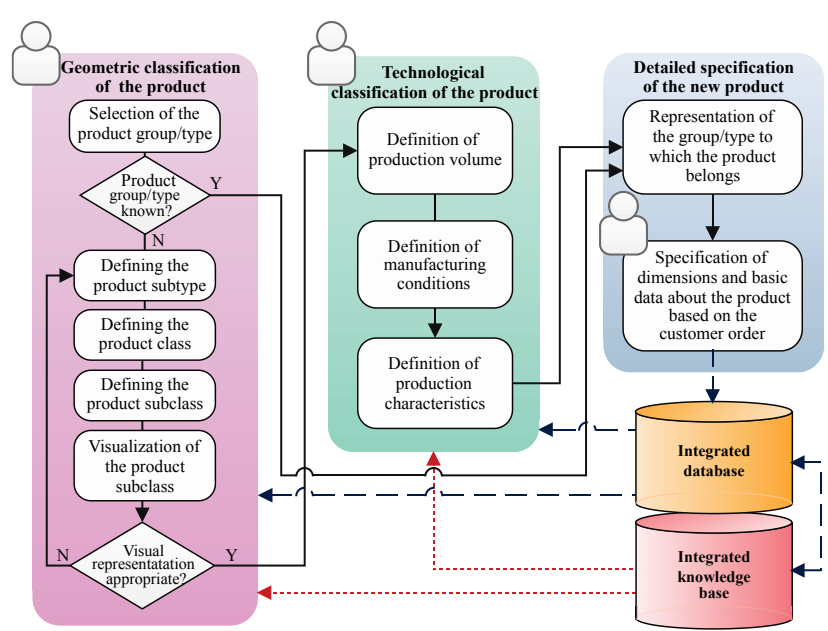

Figure 6 Workflow and dataflow in the product classification stage

Geometrical classification determines the affiliation to the specific product type or group, as well as the affiliation to the specific product subtype, class or subclass based on geometric characteristics. 
Technological classification is an interactive process that involves the definition of production volume and production conditions related to the current available production capacities. After the classification, the next step is the definition of basic information about the product and the specific raw material (Fig. 7).

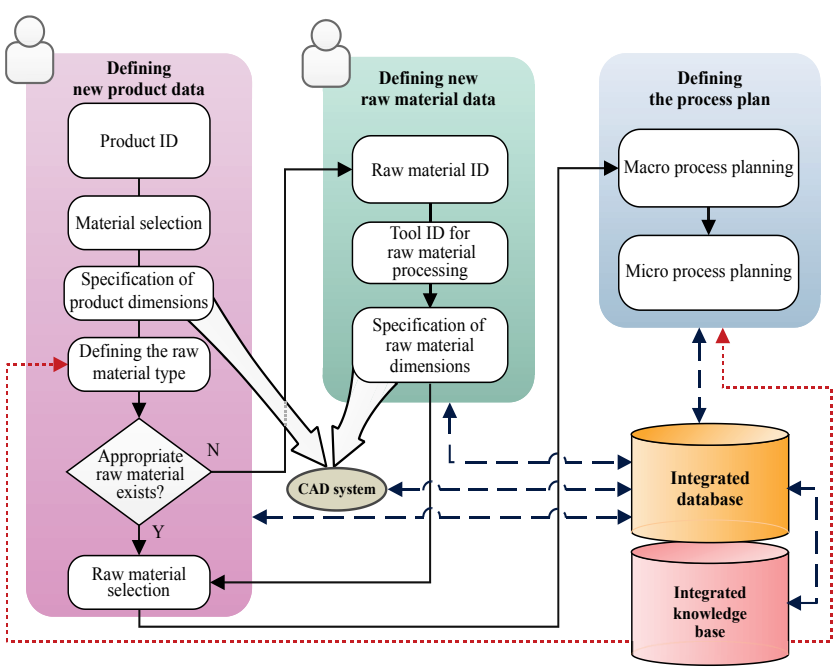

Figure 7 Workflow and dataflow in the stage of the detailed new product definition

Process planning begins with the identification of the product group or the product type, and the type of raw material (Fig. 8). The content of the identified process plan is generated and it becomes a unique manufacturing characteristic of the new product. In this way, the process plan on the macro level is defined.

Process planning on the micro level includes the definition of operations and groups of operations, as well as fixtures, tools and measuring devices. The final result is the precisely defined process plan for the given product based on which the technological documentation is generated. This also represents the output of the CAPP system.

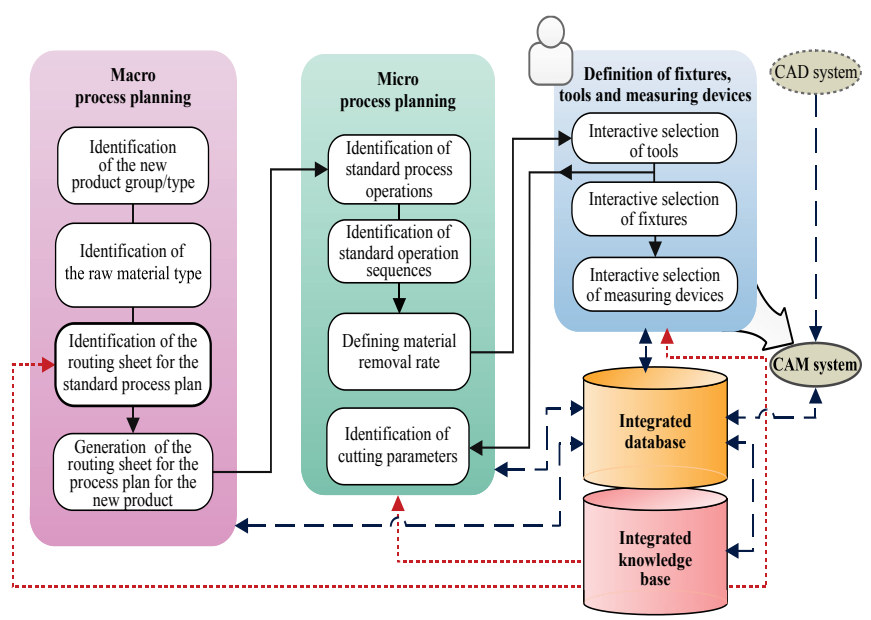

Figure 8 Workflow and dataflow in the stage of the automated generation of process plans for the new product

\section{Model of the collaborative system}

The analysis of the collaborative environment structure and its basic factors lead to the conceptual model of the collaborative process planning system (Fig. 9).

The core of this system is located within the parent enterprise A whose primary task is related to the process planning for products that are ordered by external enterprises B, C, etc.

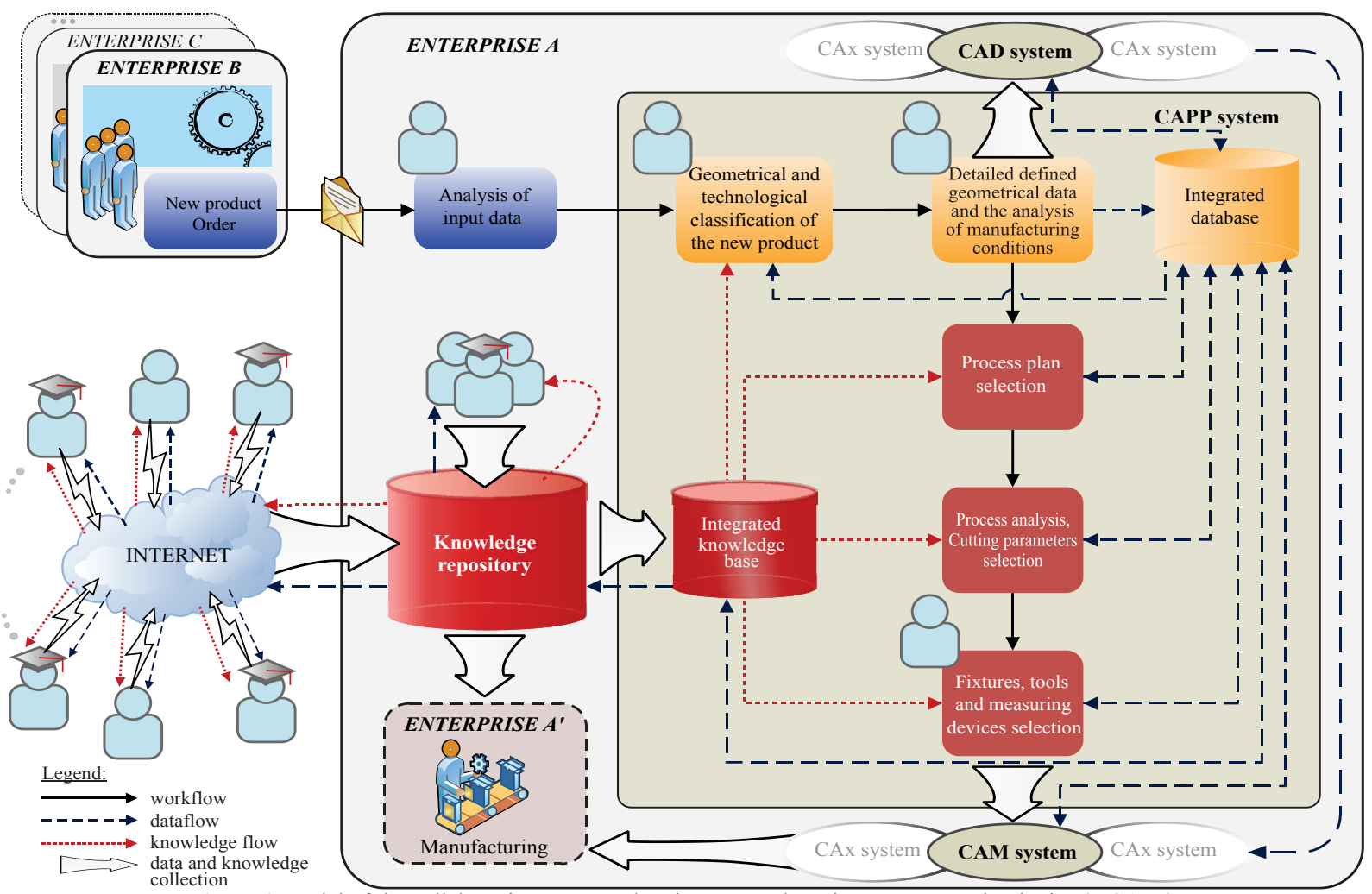

Figure 9 Model of the collaborative process planning system based on Internet technologies (e-CAPP) 
The parent enterprise uses the specialized CAPP system for automated process planning oriented to its own product family. Also, it is considered that the parent enterprise, or in this way the extended enterprise, operates on the principles of concurrent engineering while different CAx systems are simultaneously used in the development and analysis of different stages of the product lifecycle.

The work of the parent enterprise is based on the distributed process planning and manufacturing. For example, it can possess the enterprise A that deals with direct manufacturing within its facilities.

The model of the collaborative system includes two main groups of experts involved in the collaboration process:

- Engineers and experts belonging to the parent company, and

- Geographically dislocated engineers and experts belonging to the organizational structure of the extended enterprise.

Based on the needs of external enterprises, engineers and experts within the parent enterprise participate in the production planning process. They are also involved in the proposal of new manufacturing solutions, as well as the interaction with the CAPP and other CAx systems used in planning and analyses. On the other hand, dislocated engineers and experts participate not only in the evaluation of the proposed solutions, but also in the improvement of the existing ones and the proposal of new, and possibly better, process plans. Information infrastructure in the collaborative system includes different information and knowledge flows, as well as the procedures for collecting engineering and expert knowledge. It is clear that the development of the model structure requires the implementation of the modern system for data management, organization and distribution. In addition to the required dynamic control of the complex information structures, the database system must also provide an adequate protection of information that represents a business secret at the level of the extended enterprise.

\section{Conclusion}

Bearing in mind the concept of modern distributed manufacturing, i.e. e-manufacturing, it can be concluded that the presented collaborative system facilitates the global integration of distributed manufacturing enterprises, organizational units and experts who use the Internet as an effective communication infrastructure. The application of Internet technologies has enabled the access to complete manufacturing solutions for all stakeholders involved in the planning and evaluation of process plans regardless of their geographic location.

The model predicts a two-way communication and the creation of the ad hoc virtual team with engineers and experts from the area of process planning. The knowledge of all stakeholders in the collaboration is collected and organized in the knowledge repository which is available not only to manufacturing structures, but also to organizational and management structures within the enterprise. The model represents the basis that can be implemented in a modern technological preparation and can also be expanded and adapted to specific cases.

\section{Acknowledgements}

This work was supported by the project "Application of collaborative engineering for improving sustainable manufacturing process", no. 142-451-3556/2016-01, founded by the Provincial Secretariat for Science and Technological Development of The Province of Vojvodina and partially supported by Ministry of Education, Science and Technological Development of Republic of Serbia, within the project no. TR35025.

\section{References}

[1] Saric, T.; Simunovic, G.; Simunovic, K.; Svalina, I. Estimation of Machining Time for CNC Manufacturing Using Neural Computing. // International Journal of Simulation Modelling. 15, 4(2016), pp. 663-675. DOI: 10.2507/IJSIMM15(4)7.359

[2] Simunovic, G.; Svalina, I.; Simunovic, K.; Saric, T.; Havrlisan, S.; Vukelic, D. Surface roughness assessing based on digital image features. // Advances in Production Engineering \& Management. 11, 2(2016), pp. 93-104. DOI: 10.14743/apem2016.2.212

[3] Kamrani, A. K.; Nasr, E. A. Collaborative Engineering Theory and Practice. Springer Science+Business Media, New York, 2008

[4] Wang, L.; Nee, Y. C. A. Collaborative Design and Planning for Digital Manufacturing, Springer-Verlag London Ltd., 2009. DOI: $10.1007 / 978-1-84882-287-0$

[5] Valilai, O. F.; Houshmand, M. A Collaborative and Integrated Platform to Support Distributed Manufacturing System Using a Service-oriented Approach based on Cloud Computing Paradigm. // Robotics and Computer-Integrated Manufacturing. 29, 1(2013), pp. 110-127. DOl: 10.1016/j.rcim.2012.07.009

[6] Kostić, Z; Radaković, D.; Cvetković, D.; Jevremović, A; Marković, D.; Ranisavljev, K. M. Web-Based Laboratory for Collaborative and Concurrent CAD Designing, Assembling, And Practical Exercising On Distance. // Tehnicki vjesnik - Technical Gazette. 22, 3(2015), pp. 591597. DOI: 10.17559/TV-20140211115630

[7] Li, W. D.; Ong, S. K.; Nee, A. Y. C. Integrated and Collaborative Product Development Environment, Technologies and Implementations. // Series on Manufacturing Systems and Technology - Vol. 2, World Scientific Publishing Co. Pte. Ltd, 2006.

[8] Li, W. D.; Qiu, Z. M. State-of-the-art Technologies and Methodologies for Collaborative Product Development Systems. // International Journal of Production Research. 44, 13(2006), pp. 2525-2559. DOI: 10.1080/00207540500422080

[9] Kulvatunyou, B.; Wysk, R. A.; Cho, H. B.; Jones, A. Integration Framework of Process Planning Based on Resource Independent Operation Summary to Support Collaborative Manufacturing. // International Journal of Computer Integrated Manufacturing. 17, 5(2004), pp. 377 393. DOI: $10.1080 / 09511920310001607104$

[10] Kuric, I. New Methods and Trends in Product Development and Process Planning. // Academic Journal of Manufacturing Engineering. 9, 1(2011), pp. 83-88.

[11] Denkena, B.; Shpitalni, M.; Kowalski, P.; Molcho, G.; Zipori, Y. Knowledge Management in Process Planning. // CIRP Annals - Manufacturing Technology. 56, 1(2007), pp. 175-180. DOI: 10.1016/j.cirp.2007.05.042 
[12] Mandić, V.; Ćosić, P. Integrated Product and Process Development in Collaborative Virtual Engineering Environment. // Tehnicki vjesnik - Technical Gazette, 18, 3(2011), pp. 369-378

[13] Wang, L. H.; Feng, H. Y.; Cai, N. X. Architecture Design for Distributed Process Planning. // Journal of Manufacturing Systems. 22, 2(2003), pp. 99-115. DOl: 10.1016/S0278-6125(03)90008-2

[14] Milošević, M.; Antić, A; Lukić, D; Jovičić, G.; Vukman, J. Distributed Process Planning through Web-based Collaboration. // Scientific Bulletin, Serie C, Fascicle: Mechanics, Tribology, Machine Manufacturing Technology. 18, (2014), pp. 65-68.

[15] Siller, H. R.; Estruch, A.; Vila, C.; Abellán, J. V.; Romero, F. Modelling Workflow Activities for Collaborative Process Planning with Product Lifecycle Management Tools. // Journal of Intelligent Manufacturing. 19, 6(2008), pp. 689-700. DOI: 10.1007/s10845-008-0120-6

[16] Cheng, K.; Bateman, R. J. e-Manufacturing: Characteristics, applications and potentials. // Progress in Natural Science. 18, 11(2008), pp. 1323-1328. DOl: 10.1016/j.pnsc.2008.03.027

\section{Authors' addresses}

Dr. Sc. Mijodrag Milošević, Assist. Professor

University of Novi Sad, Faculty of Technical Sciences,

Trg Dositeja Obradovića 6, 21000 Novi Sad, Serbia

E-mail:mido@uns.ac.rs

Dr. Sc. Dejan Lukić, Assist. Professor

University of Novi Sad, Faculty of Technical Sciences,

Trg Dositeja Obradovića 6, 21000 Novi Sad, Serbia

E-mail: lukicd@uns.ac.rs

Dr. Sc. Stevo Borojević, Assist. Professor

University of Banja Luka, Faculty of Mechanical Engineering,

Vojvode Stepe Stepanovića 71, 78000 Banja Luka, BiH

E-mail: stevo.borojevic@unibl.rs

Dr. Sc. Goran Šimunović, Professor

Josip Juraj Strossmayer University of Osijek,

Mechanical Engineering Faculty in Slavonski Brod,

Trg Ivane Brlić Mažuranić 2, 35000 Slavonski Brod, Croatia

E-mail: goran.simunovic@sfsb.hr

Dr. Sc. Aco Antić, Assoc. Professor

(Corresponding author)

University of Novi Sad, Faculty of Technical Sciences,

Trg Dositeja Obradovića 6, 21000 Novi Sad, Serbia

E-mail: antica@uns.ac.rs 